Jurnal Predestination: jurnal of Society and Culture.

Vol .1 No.2, Maret 2021

\title{
LUDWIG WITTGENSTEIN: TOWARDS A MEANINGFUL TALK ABOUT RELIGION
}

\author{
Onos Godwin Idjakpo ${ }^{1}$ Peter. O. O. Ottuh ${ }^{2}$ \\ ${ }^{\mathbf{1}}$ Department of Religious Studies and Philosophy, \\ Delta State University, \\ Abraka, Delta State, Nigeria. \\ ${ }^{2}$ Department of Religious Studies and Philosophy, \\ Delta State University, \\ Abraka, Delta State, Nigeria. \\ Email: ottuhpeter@gmail.com
}

\begin{abstract}
Wittgenstein's profound thought had rich implications regarding religious belief and religion. In his early philosophy, silence occupies a central place to articulate what is beyond the boundary of language. Silence overcomes the limits of human language. In Wittgenstein's later philosophy, religious language and different religious languages are legitimized by the multiple uses of language. An evaluation of his linguistic philosophy and its application in religious belief reveals that despite the limitations of his philosophy, Wittgenstein has enriched the contemporary philosophy of religion. This paper discusses the meaningful talk about religion, religious speech acts and religious rituals with Wittgenstein's later understanding of the religious domain. Though Wittgenstein was not a religious man, he saw things from a religious point of view. His insight on religious belief can be seen from different perspectives. From a pragmatic perspective, religious language is very much tied up with the form of life. It emerges from the everyday shared practices of the community of believers.
\end{abstract}

Keywords : Ludwig Wittgenstein; Religion; Religious Beliefs; Religious Pluralism.

\section{INTRODUCTION}

An investigation into the philosophy of Ludwig Wittgenstein makes it clear that he was not an acknowledged follower of any established religion. When it came to participation in any organized religion, his knees were too stiff to kneel and pray (Morra 2019). At the same time, he was not totally alien to religion or religious belief. In his own words, "I am not a religious person, but I could not help seeing every problem from a religious point of view" (Morra 2019: 79). Wittgenstein was never exclusively concerned about the study of religion. In fact, an exclusive study in this field is not possible in the larger context of his later philosophy, since religion is a feature of human life that cannot be separated altogether. What Wittgenstein brought to the study of religion was a vibrant attentiveness to the religious use of 
Jurnal Predestination: jurnal of Society and Culture.

Vol .1 No.2, Maret 2021

language and the need for considering those uses in their proper context. Wittgenstein was trying to liberate religion and religious belief from the mold of abstraction to the level of the everydayness of human life. After going through some of his important philosophical themes and their implications for religion and his scattered notes on religious beliefs, one would be tempted to 'look and see' resisting the craving for generality. The prime importance is given to particulars that are understood in their proper context. Therefore, this is an attempt to understand Wittgenstein's position on religion and religious belief from a sociocultural context and letting the multi-cultural and multi-religious context remain as it is. His remarks on religious belief do not spring from any systematic thinking but from the everyday practices of human beings. Here we attempt to see them from a pragmatic point of view. Religious beliefs are inevitably related to different aspects of human life (Sasa 2018). Rituals, which play an important role in religious beliefs, have considerable influence on the life of the believer (Allam 2018). Therefore, Wittgenstein's insight in the field of religious belief can also be seen from an ethical point of view.

Here we evaluate the contribution he makes to the philosophy of religion by his pluralistic and dynamic understanding of religion and religious belief and, in doing so, try to understand the relevance of his philosophy today in revitalizing religious language. His profound thoughts on religious belief, I think, are very suitable and relevant to the present day scenario. They serve as pillars to support a pluralistic understanding of religion and religious belief in today's world.

\section{Towards an Eastern Approach}

Wittgenstein's early philosophy really contributes to the philosophy of religion. His understanding of the mystical is very much in keeping with an Eastern approach. It enriches those religious traditions which are institutionalized and dogmatized. A meaningful talk about religions and religious belief with propositional language, which pictures reality, is not possible at the early stage of his thinking.

\section{THE SPLENDOR OF THE 'SIMPLE'}

The transcendental nature of the "Divine" is common to almost all religions of the world. An understanding of early Wittgenstein's linguistic analysis makes it clear, beyond doubt, that what can be articulated in words are facts of the world. All values - religious, ethical and aesthetical ones - go beyond human language (propositional language). The last verse of Tractatus characterizes these as the realm of 'silence' (Wittgenstein \& Granger 2012). This is the realm where words fail to articulate the reality. There is a definite boundary for what can be said by scientific language. Religious language is one which is used by humans to satisfy their natural urge to go beyond the natural boundary of language. Therefore, people use religion and religious language to reach the ultimate and find self-realization. The ultimate reality for Wittgenstein is not absolute but absolutely 'simple,' in the sense it cannot be articulated in human language. Any attempt to articulate the 'simple' will make it complex. The ultimate is simple in the sense that it is that what there 'is.' Propositions express how things are in the world, but prior to this, there is something that is. That primordial is something inexpressible or which cannot be said. It is not how things are in the world that is mystical, but that the world exists (Wittgenstein \& Granger 2012). This realm cannot be articulated in words. Humans try to articulate this in religious language, but for Wittgenstein this is something beyond the realm of language. However, what is beyond expresses itself or shows itself. "There are, indeed, 
Jurnal Predestination: jurnal of Society and Culture.

Vol .1 No.2, Maret 2021

things that cannot be put into words. They make themselves manifest. They are what is mystical” ((Wittgenstein \& Granger 2012: 22).

\section{Experience of the Divine}

The realm that is beyond language is not beyond the reach of human experience, but it cannot be formulated in meaningful propositions. Wittgenstein makes a difference between the experience that something is, and the experience of how something is. Experience in the normal sense is not experience that something is, but experience of how something is. Compared to the ordinary understanding of experience as how something is, the experience of something is not an experience, but it is a different type of experience. This realm which is beyond language can be experienced and comprehended. We fail at the linguistic level but not in the experiential level. Whatever the name we give for this realm it is a projection of our linguistic limitation. The attempt to name the experience of what is beyond - that it exists or something is, what Wittgenstein calls the mystical - cuts short the perfection of the reality.

Wittgenstein seems to have realized the authentic spirit of religion in his Tractatus, though it is fully accomplished in his later philosophy. The experience of what there is, is mystical. Religious experience, according to him, is so sublime that it cannot find full expression in words. The transcendental nature of religion places it beyond the reach of propositional language. Any attempt to articulate this experience in words falls short of perfection, and the articulation will be what Wittgenstein calls nonsensical. The last sentence of Tractatus reminds us of his preference for silence in what is beyond and what we call religion and religious experience. "What we cannot speak about we must pass over in silence" (Wittgenstein \& Granger 2012: 7).

\section{De-dogmatization of Religion}

Though language in his early philosophy was more deterministic and static, there is room for advancement and improvement in his thought. At the end of the Tractatus, Wittgenstein speaks against the deterministic tendency in philosophy. Propositions are used as steps (as a ladder) to climb up beyond; it is to be thrown away after climbing. I think this can be applied to religion for better understanding. Philosophers of religion speak of the proofs for the existence of God and theories concerning his presence in the world and life after death. These proofs and theories are finished products, established for once and all. Wittgenstein, by advocating silence towards religious language, poses a challenge to traditional dogmatized religions which use scientific and propositional language to establish religious truth. This makes human life static and devoid of dynamism. This can lead to fanaticism and fundamentalism at large. The purpose of language is to convey information and picture facts. Religious language is beyond this scope since it is nonsense. The language of religion has no place in human life.

Religious teachings should be updated and should even give way to new ones in the course of time. Wittgenstein raises serious challenges to established and institutionalized religions that consider themselves a set of doctrines and dogmas that cherish a tendency that may lead to exclusivism and intolerance. This dynamic nature of religious belief is more expressed in his later philosophy which will be discussed later in this work. 
Jurnal Predestination: jurnal of Society and Culture.

Vol .1 No.2, Maret 2021

\section{Towards a "Wordless Faith"}

Wittgenstein seems to have advocated a religion of speechless faith in his early philosophical career. Religion is seen as a way of life - a way of acting out rather than talking about. He was all against the doctrinization of any religious tradition. Paul Engelmann rightly points out that "any doctrine uttered in words is the source of its own misconstruction by worshipers, disciples and supporters" (Wawrzyniak 2003:133). The divine is simple, and any attempt to doctrinize it will make it complicated. The doctrine itself becomes a source of misconstruction and misinterpretation.

"Wordless faith," which Paul Engelmann attributed to Wittgenstein's understanding of religion, can be understood in different ways, in line with his later understanding of religion as a way of life. Wittgenstein is all against giving scientific proofs and historical evidence for religious beliefs. In another sense, action is more important than word in religion as a way of life. What is important is not the articulation of experience but the experience itself that something exists. It is either an experience of 'wonder' or it can be interpreted as silent listening to the primordial saying and a response in silence (Mulhall 2011). This new way of understanding religion as a way of doing rather than talking may bring about reconciliation between conflicting ideologies and religious traditions. We cannot fully agree with the followers of Wittgenstein who condemn all doctrines as sources of misconstruction, since we know from our everyday experience that the articulation of certain experiences and actions may be guidelines for better human behavior.

His preference for silence in the matters of the Divine and whatever we call religious is one thing which is very much appreciated and loved by Eastern thinkers; they consider silence as the best way of articulating the Divine, and the best method of expressing religious experience. Silence as the way to experience the Divine as well as to convey one's inner experience of the Divine has been adopted by almost all world religions especially those of the East, where we have Buddha and the sages who loved silence so much. We can find some similarities between Wittgenstein's later philosophy and the teachings of Zen Buddhism. Language is normally understood as an expression of thought. It is the bridge between the thought of the one who speaks and the one who hears. Zen Buddhism argues that understanding is possible even without thought. This is what they call 'just doing.' Wittgenstein's use of mystical in his philosophy is in the sense that it is a matter of practice not of words and thought (Arnswald 2009: 383-884). "Don't think, but look." Thinking will distort the perception of reality. Practice, which Wittgenstein advocates, and the Buddhist view of 'just doing' is somewhat similar. The same view is postulated when Wittgenstein said: "I could well imagine a religion in which there are no doctrines, so that nothing is spoken. Clearly, then, the essence of religion can have nothing to do with what is said - rather: if anything is said, then that itself is an element of religious behavior, and not a theory" (Rono 2018: 336-337). In this sense, Wittgenstein's understanding of mystical is somewhat parallel or complementary to Eastern approach to religion and religious matters as against the Western tendency of conceptualizing the Divine. There is certain similarities between Wittgenstein and Taoist thinkers on that there are realities that cannot be expressed in language. However, conceptualization is a part of human activity but really a second order activity.

Religion belongs to the realm of transcendence since it remains inexpressible and belongs to the realm of showing. Language fails to express what is beyond the boundary of language. Transcendence in Wittgenstein is not only inexpressible in language but also 
Jurnal Predestination: jurnal of Society and Culture.

Vol .1 No.2, Maret 2021

incomprehensive (Wittgenstein 1965). This understanding of transcendence is much closer to the notion of Absolute in Advaita Vedanta. The Ultimate Reality cannot be described in language since language can describe only empirical reality. In this sense, Wittgenstein's understanding of religious transcendence has a striking similarity with that of Sankara. Wittgenstein's concept of transcendence is absolutist transcendence since it is both beyond cognition and beyond experience. It is indescribable and incomprehensible.

\section{Towards Religious Pluralism}

Wittgenstein, in his personal life, had very positive approach to the plurality of religious traditions. "All religions are wonderful, even those of the most primitive tribes. The ways in which people express their religious feelings differ enormously" (Wawrzyniak 2003: 102). Wittgenstein's talk about religion and religious belief can be traced back to the 1933 lectures where he features religious beliefs with varieties of the grammar of religious utterances. The use of words like "God," "souls" etc. are with various grammars. The possibility of singular grammatical usage for religious utterances is ruled out in his later thought. Wittgenstein is concerned about the variety of ways words are used in religious settings and the variety of roles that religious beliefs play in the life of people.

Wittgenstein's later understanding of language has far-reaching implications in the philosophy of religion. The linguistic analysis based on the language-game and form of life has a wide range of possibilities. Language is a collection of language-games, and language-games are collections of customs and institutions in which words play their role in their unique contexts. Words enjoy countless heterogeneous roles in the language-game. This legitimizes linguistic pluralism as well as religious pluralism. This later linguistic view applied to religion and religious belief can explain or give a sound basis for the reality of manifold religions existing in the world.

\section{Wittgenstein, a Challenge to Religious Exclusivism}

Wittgenstein in his linguistic analysis, has presented the plurality of language by the notions of the language-game and family resemblance. These notions have played a vital role in his understanding of language. In its application to religious belief, it has a wide range of implications. What is common to different religious traditions? What we do have between the different religious traditions is nothing but family resemblance. At the surface level, there seems to be some commonality. There are some similarities and resemblances comparable among family members. So the multiple religions existing in the world are seen as members of the same family. However, Wittgenstein asserts that there is nothing common among them. The multiple language-games we play in our lives are distinct and different from another in their nature. Even though all the games we play fall under the name 'game,' none of them exhausts the meaning of the word 'game' is. For Wittgenstein, none of the religious traditions can fully exhaust what is meant by religion, nor can a particular religion explain what religion is. This notion of family resemblance is really a challenge to the exclusivist and inclusivist understanding of religion which is basically founded on mono-foundationalistic epistemology, which presupposes common bedrock of religious practices. No particular religion can contain religion as a whole, but it is part of religion. It cannot be reduced to any particular religion. Each of the religious traditions comes within the definition of religion without exhausting the whole of the definition (Nagl 2017: 265). 
Jurnal Predestination: jurnal of Society and Culture.

Vol .1 No.2, Maret 2021

The notion of family resemblance is useful not only among different religions but also among different traditions within a religion. Besides inter-religious relations, Wittgenstein's philosophy promotes intra-religious relations. There is possibility of a variety of religious experience and religious traditions within the same religion. His philosophy really poses a challenge to the modern tendency to look for the commonality among different religions or at least different traditions in the same religion, especially in India where the Hindutva force is trying to homogenize the diverse traditions of India. The co-existence of diverse religions and religious beliefs is supported by a later entry of Wittgenstein. His introduction of the notion of incommensurability helps to safeguard the uniqueness of each religion without contradicting each other. A believer is normally one who accepts the main doctrines of a religion and participates in the activities related to rituals and worship. Conversely, an unbeliever is one who does not accept those particular doctrines and participation in the religious practices which a believer does. The meaning of believer and unbeliever depends on the context in which it is used. For Wittgenstein, the meaning of a word emerges from the use of it in particular contexts. A Christian may be a believer in the context of Christianity, but he may be an unbeliever in the context of Hinduism. An unbeliever is not an atheist in all the cases; he may be a follower of a different religious tradition. Thus the disagreement between a believer and nonbeliever has various dimensions (Shabbir 2010: 176).

Based on the doctrine of incommensurability, one can argue that an unbeliever cannot contradict the religious belief of a person. The believer and the unbeliever are using different pictures. The particular picture used by the believer does not play any significant role in the life of the unbeliever. One who follows a particular religion cannot contradict the follower of another religion. Therefore, there is no point in excluding other religions or making a claim of the sole possession of the truth. One religion cannot claim superiority over another because both are using different pictures. There is nothing common between them at the depth level, but there exists some sort of similarity. Both are using a picture, but they are using different pictures differently. Therefore, the uniqueness of each religious tradition is safeguarded. Religious fundamentalism and religious exclusivism have become major evils in our religiously pluralistic world. Even though the universality of truth is taken for granted, the knowledge of this truth may not be universal. It is not relative though the knowledge of the truth can be relative. Religious exclusivism is the attitude in which a religion or religious tradition claims the absolute monopoly of knowledge of the ultimate reality. There are different religions existing in the world with a variety of knowledge claims. The problem is who is correct? Historical research would show the barbarous and brutal intolerance of one religious tradition towards other religious traditions. This, beyond doubt, is the result of religious exclusivism. Cardinal Newman has rightly commented on this, "Oh, how we hate one another for the love of God" (Tanney 1994: 21). Religious tolerance means to accept one's right to hold a particular religious belief. It does not mean to accept the content of that particular belief (Tanney 1994).

Wittgenstein is really posing a challenge to the tendency of exclusivism and inclusivism. The essentialist position that all religions are essentially one and the differences are accidental is untenable for Wittgenstein, since it destroys the uniqueness of each religion. Wittgenstein safeguards the uniqueness of each religious tradition by his notions of family resemblance and incommensurability. His position is helpful for inter-religious relations as well as intra-religious relations - relations within the same religion. Wittgenstein is really a 
Jurnal Predestination: jurnal of Society and Culture.

Vol .1 No.2, Maret 2021

challenge to the exclusivist tendency which has shed much blood in the name of religion in history, and to the fundamentalist attitude, which is really untenable in a pluralistic society.

Religious inclusivism is another matter of attention here which also is a stumbling block to inter-religious relations. Religious inclusivism is a position in which one holds that one's religion has the sole possession of the knowledge of the ultimate reality and other religions are included in it as subsidiaries, as something incomplete. This position also is not a healthy one. I think Wittgenstein's linguistic philosophy in its religious application contributes to inter-religious relations. It can serve as a basis for understanding religious plurality. His philosophy paves the foundation for an attitude of appreciation, respect and love for others' religious beliefs. Wittgenstein's followers have different views regarding whether we can consider religious belief as a language-game. D. Z. Phillips (2017) is one of those who uphold the view that religious belief can be considered as a distinctive language-game. There are many who think that we cannot consider religious language or belief as a distinctive language-game on the basis that religious belief may look like hobbies and something with which men occupy themselves on weekends. They also criticize on the suspicion that religious belief is placed outside any possible criticism (Vinokurov 2018: 57). Besides, Wittgenstein's family resemblance theory may lead to absolutizing of one's own position, and that is as equally dangerous as exclusivism or reductionism.

\section{Varieties of Understanding of Religion and Religious Belief}

In Wittgenstein's philosophy, there is a possibility of varieties of understanding of religion from different perspectives. From the beginning to the end of his philosophical career, Wittgenstein was concerned with religious beliefs. A serious investigation into his religious thought provides us with the varieties of understanding of religion and religious beliefs in his approaches. Wittgenstein approaches religion from different points of view: religious, cultural, pragmatic and ethical. An attempt to understand religion and religious belief in a variety of ways can construe the meaning of religious belief and express it in meaningful talk.

\section{A Religious Point of View}

Wittgenstein extensively covered vast varieties of philosophical topics during his career. In his writings, the philosophy of religion was not a central concern. However, religion and religious matters are pervasive throughout his writings. Though Wittgenstein was not a religious man he could see every problem from a religious point of view. "I am not a religious man: but I cannot help seeing every problem from a religious point of view" (Lerner 1995: 79). He may not have subscribed to any particular religion or religious creed. However, it is not necessary to practice religion in order to discuss a religion. Rather, it would be helpful to describe a practice to discuss about religion (Lerner 1995). His early work was preoccupied with religion as the "mystical": that which is higher and transcendental. Wittgenstein was serious about religion and religious beliefs and committed to do them "wordlessly." Thus, Tractatus has a religious point of view which cannot be expressed in words. There is no space for meaningful talk about religion at this stage.

Though his later work, Philosophical Investigations, has no direct assertions about religious beliefs some sort of religious point of view can be attributed by the application of some of his philosophical notions to religious beliefs and religion. When applied to religion, the notion of the language-game and form life in his understanding of meaning, becomes distinct. Religion as form of life with its restricted autonomy is mostly hailed by Wittgensteinians, such as Winch, Clark and D.Z. Philips. In the later philosophical notes, 
Jurnal Predestination: jurnal of Society and Culture.

Vol .1 No.2, Maret 2021

Lectures on Religious Belief, Remarks on Frazer's Golden Bough and Culture and Value, Wittgenstein has a mature description of religious beliefs and religion. From a religious point of view, his remarks on religious beliefs indicate a passionate commitment, detaching from any sort of historical evidence or scientific proofs. From this perspective, religious beliefs gained the status of a special category pointing out Wittgenstein's departure from dogmatic and institutionalized religion. From this perspective, religious beliefs are a matter of passion, fear, trust and awe not of proof and evidence. It is a matter of heart and soul not of reason and intellect. Wittgenstein was, therefore, able to view the problems from a religious point of view.

\section{A Pragmatic Point of View}

Wittgenstein's reflection on the domain of religion and religious belief echoes the position of pragmatic philosophers. The pragmatic aspect of Wittgenstein's religious thought takes its root in different directions and culminates in all directions in the form of life. Wittgenstein's Lectures on Religious Belief establishes a fundamental relationship between religious belief and the form of life. Later in his notes, Culture and Value and Remarks on Golden Bough, the relationship between religious belief and form of life becomes deeper (Dienstag 1998). At this stage, Wittgenstein insists that religious belief should not be viewed from a theoretical or an intellectual point of view. Though Wittgenstein insists on a religious point of view, such a domain is very much rooted in the culture and shared practices of a community. This is a realistic approach to the relation between religious belief and communal practices. Religious faith and religious rituals express the existential concern of the participating community. The link between religious belief and form of life confirms the pragmatic point of view. Religious belief bases its certainty and justification on the form of life, totality of shared beliefs and not on theoretical and scientific bases.

Any speech act in religious discourse is an expression of the existential concern of the partakers of religious beliefs. On the one hand, the gap between what they believe and what they live is reduced to the minimum in the pragmatic approach of Wittgenstein. On the other hand, the effects of the belief in the life and conduct of the believer is important. Religious belief has the power to regulate the believer's life. In Wittgenstein's philosophical and religious thought, action has an important role. Theological demands for the proof of God's existence have little value in religion. The role of deeds and the importance of changing one's life gain emphasis in his philosophy. "For Wittgenstein, the essential thing in a religious life was not the acceptance of doctrines or creeds but works. To Drury, Wittgenstein has said that his belief was that "only if you try to be helpful to other people will you find your way to God" (Dienstag 1998: 20). In the later philosophical period, the main current of his thinking is his insistence that our everyday concept requires a basis of acting and doing. Wittgenstein places a greater emphasis on the role of action in his later philosophy. Though every action takes place in the background of system of beliefs, Wittgenstein suggests that action precedes thought in his remarks On Certainty (Dienstag 1998: 411). Action and thought are intertwined in his later philosophy. His thoughts outlined in On Certainty are shaped within the framework of Philosophical Investigations. Language comprises of language-games which are complicated forms of life including building, praying, telling jokes, reporting and playing games (Morra 2019: 23). Wittgenstein maintains that the ground or the end is not some proposition but acting. Our actions form the background against which the language-games take place. Wittgenstein, in his later thought, leans more towards a pragmatic philosophy. "So I am trying to say something that sounds like pragmatism" (Vinokurov 2018: 422). His pragmatic thought that is 
Jurnal Predestination: jurnal of Society and Culture.

Vol .1 No.2, Maret 2021

rooted in action and use of words, applied to religion and religious beliefs, helps us understand the meaning of such usage. The usage of words like "God" or "soul" do not lead us to the questions of "does God exist?" or "What is the mode of God's existence?" It is rather how the words "God or "soul" are used and how they are useful in the lives the people who use those or similar words in particular contexts.

The pragmatic point of view can be understood in the convergence of culture and the shared practices of a community of believers. "In Wittgenstein's thought, the anthropological and existential viewpoints combine in the link that unites belief with a form of life- i.e. with a pattern of conduct and a context made of rules and shared practices" (Vinokurov 2018: 19). Religious beliefs, their utterance and ritual forms culminate in the lives of the people who collectively share the same mode of life patterns. Religious beliefs have their origin in the collective and shared practices of the community or culture on the one hand, and their effect in the life of the believer on the other. The former is communitarian or cultural and the latter is more subjective. However, the latter has a communal effect in a larger perspective. A picture of religious belief is similar to holding up a mirror to reflect our own nature. Wittgenstein's pragmatic approach to religious beliefs offers a more coherent understanding of religious beliefs. The possibility of varieties of understanding of religious beliefs is offered in a religiously pluralistic world without contradicting each other.

\section{A Cultural Point of View}

Wittgenstein, in his later thought has a very pessimistic attitude toward culture. It seems that he was heavily influenced by Oswald Spengler's The Decline of the West. Wittgenstein had a very pessimistic attitude about the contemporary culture. Perhaps he expressed a doubt because his thought on religion would be misunderstood in the darkness of this time (Kidd 2012). The spirit of his philosophy was against the spirit of the time. Wittgenstein claims that his philosophy is opposed to cultural decline. However, there is no such mention of cultural decline in the Philosophical Investigations. The cultural decline is internally connected to his views on religious decline. Wittgenstein could see the religious beliefs from a cultural point of view. Religious beliefs and practices expressed the spirit of the culture. This is declining and, therefore, what is expressed in ritualistic practice is a declined cultural perspective. His pessimistic attitude to the possibility of religious expression in language emerged from his singular understanding of language at the early phase of his philosophy. However, his pessimistic attitude, though not severe as in the early phase, is linked to the emergence of modern civilizations.

In the background of the decline of culture, it is impossible to express religious beliefs. Wittgenstein shared Spengler's idea of obstacles to artistic expression due to cultural decline. Religion undergoes the fate as art. Religious inexpressibility, in later Wittgenstein, is connected to his cultural concerns. When the cultural setting is in its proper place, religious expressions become meaningful. The cultural surrounding necessary for religious expressions is disappearing due to cultural decline. From a cultural point of view present cultural context is not suitable for expressions of religion. The meaning of religious expressions is bound up with social surroundings and cultural settings (Kidd 2012).

\section{An Ethical Point of View}

Wittgenstein, throughout his philosophical career, maintained some sort of affinity between religion and ethics. An attempt to understand the relevance of Wittgenstein's philosophy unveils its relation to human life. His philosophy, in general, and the philosophy of 
Jurnal Predestination: jurnal of Society and Culture.

Vol .1 No.2, Maret 2021

religion, in particular, is dependent on human existential dealings. In his early writings, Wittgenstein insists that religious beliefs along with ethical values are transcendental. Religious assertions are as inexpressible as ethical values. Religion and ethics do not belong to the world of facts. Values along with religious belief cannot be said but only shown. Ethics and religion converge at the point that it is transcendental and any attempt to express that which is transcendental will result in nonsense. In his Lectures on Ethics, Wittgenstein links the inexpressibility of ethical values and inexpressibility of religious values. He makes a distinction between relative value and absolute value. He claims that statements of relative value can be expressed in factual statements, and statements of absolute value cannot be expressed in factual statements (Díaz 2019: 38-39). The inexpressibility of ethical or absolute value also applies to religious value in his lectures. Wittgenstein continued this approach even in his later remarks. "What is Good is Divine too. That, strangely enough, sums up my ethics" (Díaz 2019).

Wittgenstein was inspired to identify values with the mystical and excluded values from the intelligible world. He was able to integrate value into the life flow of human life (Graham 2014). The meaning of life - not in the sense of the purpose of life - is the sense of the world that belongs to the outside of the world. He makes a distinction between two godheads; the world, on the one hand, with its factuality, and independent I, on the other hand, with meaning of life and God. It is the "independent I" that is the basis of a good and happy life. Thus the "independent I" has an important role in the mystical thought of Wittgenstein. Interestingly, Wittgenstein was reported to have said that the purpose of Tractatus is ethical. Wittgenstein's talk about the religious terms like "god," "soul" and "immortality of soul" seems to be equated with ethical expressions even during the later stage of his philosophy. "I have always wanted to say something about (the) grammar of ethical expressions, or e.g. of God" (Kidd 2012: 411).

Wittgenstein's understanding of religious life as a picture that regulates the life of the believer has many ethical implications. The purpose of religious belief, though not expressed in propositions, is ethical. Religious beliefs serve as guiding principles and standing right in front of human beings. Religious beliefs have an important role in forming a moral conscience and regulating man's actions which involve moral standards. Thus, religious beliefs have a considerable influence on the moral behavior of human beings. However, an over emphasis on the moral perspective can reduce Wittgenstein's view on religion to mere morality. Morality is an element in religious life. The presence of various rituals and the existence of various sacred scriptures help to shape moral responses and religious forms of life. It is within the religious forms of life that moral responses are formulated (Dienstag 1998). Though Wittgenstein linked ethics and religion tightly, it is not right to consider his thinking as a reductive view of religion. In the reductive view, religion is simply viewed as morality associated with certain emotions and narratives. Wittgenstein is far distanced from such a consideration.

\section{A Non-Metaphysical Point of View}

Wittgenstein has influenced the discipline of philosophy as well as its subsidiary fields including the philosophy of religion. He has produced two different philosophies yet equally brilliant and mainly centered on the philosophy of language with a non-metaphysical approach. Wittgenstein tried to avoid metaphysical concerns from the beginning. Any metaphysical reflection is inseparable from metaphysical anxiety. Freedom from metaphysical anxiety and overcoming misery are achieved through living the presence. "I cannot bend the happenings of 
Jurnal Predestination: jurnal of Society and Culture.

Vol .1 No.2, Maret 2021

the world to my will. I am completely powerless. I can only make myself independent of the world, and so in a certain sense master it, by renouncing any influence on happenings" (Phillips 2017: 140). Those who accept the world as it is live without fear and hope. His nonmetaphysical approach is much more evident in his later writings. "What we do is to bring words back from their metaphysical use to everyday use" (Phillips 2017: 140). Wittgenstein has made an attempt to bring religious beliefs and discourse to their original home, centered on the life of the community of believers. This approach is exposed by exploring the meaning his parenthetical remark, "Theology as Grammar" (Phillips 2017: 143) based on his new approach to the theory of meaning.

Wittgenstein's renewed approach to language and religious belief has a significant influence on the traditional Judeo-Christian approach to religious belief which is highly metaphysical. Traditional religious beliefs are highly metaphysical with their doctrinal and dogmatic character. After Wittgenstein, there was a change in the approach and in the application of religious belief, a change from theory to practice. The grammar of religious belief changed from abstract and systematical theories to the simple everyday life of human beings. The meaning of religious language was divorced from its doctrinal footings and found its meaning in ordinary life situations, where one used them in religious celebrations and ritual practices (Nagl 2017). Wittgenstein's remarks on religion and religious belief associated with the language-game and form of life are beyond explanation since they do not rest on any metaphysical or doctrinal foundation. They do not need any ground or rationalization. Any metaphysical or scientific grounding is incoherent in religious beliefs for Wittgenstein. However, Wittgenstein is not moving to an irrationalism or rejecting any creeds or doctrines in religion. What is important in religion is a commitment and a way of acting that requires the reorientation of one's life. A system of beliefs is inescapable in any religion. A commitment to that system of belief gains priority in genuine religious belief. The non-speculative aspects of religion as a way of life are more attractive for Wittgenstein. For him, religious beliefs are matters of heart and soul not of speculative intelligence (Arnswald 2009).

\section{CONCLUSION}

From the above study, we can conclude that Religious beliefs have their effects on the believer in a subjective and communal level by directing and regulating their lives. Religious language and religious rituals express the very existential concern of the believers, requiring no theoretical or scientific explanations. From a spiritual point of view, religious beliefs are seen as passion and trust without having the ground of reason or historical evidence, and without slipping back to fundamentalism and terror. At this stage, actions speak louder than words. In a way, Wittgenstein is returning to the mysticism of his early philosophy. Viewing Wittgenstein's thoughts on religious beliefs from different angles enables us to speak of religion and religious beliefs more meaningfully. Though any talk on religion and religious matter is nonsense, it became important nonsense in his later philosophy, with its ability to manifest itself in human life and center on the important aspects of human life. Religious thoughts became humanistic, able to find their expression meaningfully in human life and not necessarily in words.

\section{REFERENCES}


Jurnal Predestination: jurnal of Society and Culture.

Vol .1 No.2, Maret 2021

Allam, O. S. (2018). Unmasking "Alekwu" Religious Experience among the Idoma PeopleGroup of Nigeria. GNOSI: An Interdisciplinary Journal of Human Theory and Praxis, 1(2), 118-130.

Arnswald, U. (2009). In Search of Meaning : Ludwig Wittgenstein on Ethics, Mysticism and Religion. In In Search of Meaning: Ludwig Wittgenstein on Ethics, Mysticism and Religion. https://doi.org/10.26530/oapen_422396

Asuquo, O. O. (2019). Humanism as a Category of Religious Alternative. GNOSI: An Interdisciplinary Journal of Human Theory and Praxis, 2(1), 30-36.

Díaz, J. A. (2019). Wittgenstein y la religión. In Ensayos de Filosofía II (pp. 61-90). https://doi.org/10.2307/j.ctvb6v6n5.6

Dienstag, J. F. (1998). Wittgenstein among the savages: Language, action and political theory. In Polity (Vol. 30, Issue 4, pp. 579-603). https://doi.org/10.2307/3235256

Graham, G. (2014). Wittgenstein and Natural Religion. In Wittgenstein and Natural Religion. https://doi.org/10.1093/acprof:oso/9780198713975.001.0001

Kidd, I. J. (2012). Oswald Spengler, technology, and human nature. In European Legacy (Vol. 17, Issue 1, pp. 19-31). https://doi.org/10.1080/10848770.2011.640190

Lerner, B. D. (1995). Winch and Instrumental Pluralism. Philosophy of the Social Sciences, 25(2), 180-191. <Go to ISI>://A1995RA76400002

Morra, L. (2019). Wittgenstein and Piccoli. Wittgenstein-Studien, 11(1), 1-29. https://doi.org/10.1515/witt-2020-0002

Mulhall, S. (2011). Wittgenstein on Religious Belief. In The Oxford Handbook of Wittgenstein. https://doi.org/10.1093/oxfordhb/9780199287505.003.0034

Nagl, L. (2017). „James's book The Varieties of Religious Experience does me a lot of good.”. Wittgenstein-Studien, 8(1). https://doi.org/10.1515/witt-2017-008

Phillips, D. Z. (2017). Just say the word: Magical and logical conceptions in religion. In Religion and Wittgenstein's Legacy (pp. 139-159). https://doi.org/10.4324/9781315244761-8

Rono, J. (2018). Revolutionary Traits in Wittgenstein and St. Paul. Philosophy and Theology, 30(2), 333-359. https://doi.org/10.5840/philtheol201944106

Sasa, M. S. (2018). Vico and Man's Creation of Institutions: A Backward Journey to Human Root. GNOSI: An Interdisciplinary Journal of Human Theory and Praxis, 1(2), 110117.

Shabbir, A. (2010). Ludwig Wittgenstein: Ethics and Religion (review). Philosophy East and West, 60(3), 422-424. https://doi.org/10.1353/pew.0.0109

Tanney, J. (1994). Wittgenstein's centenary essays,. History of European Ideas, 18(6), 970973. https://doi.org/10.1016/0191-6599(94)90366-2

Vinokurov, V. (2018). LUDWIG WITTGENSTEIN: LANGUAGE AND STRUCTURES OF LIFE. 5th SGEM International Multidisciplinary Scientific Conferences on SOCIAL SCIENCES and ARTS SGEM2018, Ancience Science, 5. https://doi.org/10.5593/sgemsocial2018h/21/s06.033

Wawrzyniak, J. (2003). Ludwig Wittgenstein a Religia - Wprowadzenie [Ludwig Wittgenstein and Religion - Introduction]. Forum Philosophicum, 8, 288-291. https://doi.org/10.5840/forphil2003834

Wittgenstein, L. (1965). I: A Lecture on Ethics. The Philosophical Review, 74(1), 3. https://doi.org/10.2307/2183526

Wittgenstein, L., \& Granger, G. (2012). Tractatus logico-philosophicus. Paris: Gallimard. 
Jurnal Predestination: jurnal of Society and Culture.

Vol .1 No.2, Maret 2021 